\title{
Stimulation of cholesteryl ester synthesis in human monocyte-derived macrophages by low-density lipoproteins from Type 1 (insulin-dependent) diabetic patients: the influence of non-enzymatic glycosylation of low-density lipoproteins
}

\author{
T.J.Lyons ${ }^{1}$, R. L. Klein ${ }^{1}$, J. W. Baynes ${ }^{2}$, H.C.Stevenson ${ }^{3}$ and M.F. Lopes-Virella ${ }^{1}$ \\ ${ }^{1}$ Department of Medicine, VA Medical Center and Medical University of South Carolina, Charleston, and \\ ${ }^{2}$ Department of Chemistry, University of South Carolina, Columbia, South Carolina; \\ ${ }^{3}$ Biological Modifiers Program, National Cancer Institute, National Institutes of Health, Frederick, Maryland, USA
}

\begin{abstract}
Summary. Diabetes mellitus is an independent risk factor in the development of atherosclerosis. In this study we aimed to demonstrate whether there is an abnormal interaction between low-density lipoproteins from diabetic patients and human macrophages. We measured cholesteryl ester synthesis and cholesteryl ester accumulation in human monocytederived macrophages (obtained from non-diabetic donors) incubated with low density lipoproteins from Type 1 (insulindependent) diabetic patients in good or fair glycaemic control. Low density lipoproteins from the diabetic patients stimulated more cholesteryl ester synthesis than low density lipoproteins from non-diabetic control subjects (7.19 \pm 1.19 vs $6.11 \pm 0.94 \mathrm{nmol} / \mathrm{mg}$ cell protein $/ 20 \mathrm{~h}$, mean $\pm \mathrm{SEM}, p<$ 0.05 ). The stimulation of cholesteryl ester synthesis by low density lipoproteins isolated from diabetic patients was paralleled by a significant increase in intracellular cholesteryl ester accumulation $(p<0.02)$. There were no significant differences in the lipid composition of low density lipoproteins between the diabetic and control groups. Non-enzymatic gly-
\end{abstract}

cosylation of low density lipoproteins was higher in the diabetic group $(p<0.01)$ and correlated significantly with cholesteryl ester synthesis $(r=0.58)$. Similarly, low-density lipoproteins obtained from non-diabetic subjects and glycosylated in vitro stimulated more cholesteryl ester synthesis in macrophages than control low density lipoproteins. The increase in cholesteryl ester synthesis and accumulation by cells exposed to low density lipoproteins from diabetic patients seems to be mediated by an increased uptake of these lipoproteins by macrophages. This study suggests that glycosylation of low density lipoproteins to the extent occurring in diabetes may alter their interaction with human monocytederived macrophages and may lead to increased intracellular cholesteryl ester accumulation. The results suggest a possible mechanism by which hyperglycaemia may contribute to the acceleration of atherosclerosis in diabetes.

Key words: Diabetes, LDL metabolism, glycosylated LDL, cholesteryl ester synthesis, human macrophages.
A link between severity of hyperglycaemia and the development of diabetic complications has long been suspected, but the possible mechanisms involved are not yet clear [1]. Increased non-enzymatic glycosylation [2] of proteins, which may profoundly affect their metabolic behaviour, provides one attractive hypothesis to explain this link. This process involves the adduction of open-chain glucose molecules to the primary amino-groups of proteins [3]. Increased glycosylation has been implicated in the development of various complications of diabetes [4], including cataract formation $[5,6]$ connective tissue abnormalities $[7$, $8]$ and atherosclerosis $[9,10]$. The latter complication is particularly important since it is one of the major causes of morbidity and mortality in diabetes [11].

Abnormalities of lipoprotein metabolism are intimately related to the development of atherosclerosis, and several studies have been performed to measure and assess the effect of glycosylation of apolipoproteins. Increased glycosylation of all major classes of apolipoproteins has been demonstrated in diabetes [12]. The effect of glycosylation on the interactions of low density lipoproteins (LDL) with cultured cells has also been studied, but only using LDL glycosylated in vitro $[9,10,13]$. These studies showed that recognition of glycosylated LDL by the classical LDL receptor on human fibroblasts is markedly impaired when there is extensive glycosylation. Lesser degrees of in vitro glycosylation, thought to be comparable to those occurring in vivo in diabetes, also impaired the recognition of LDL by fibroblasts [14].

Furthermore, the degree of impairment in the uptake of glycosylated LDL was related to the degree of glycosylation [14]. Studies using LDL isolated from 
Table 1. Clinical characteristics of diabetic patients and control subjects

\begin{tabular}{|c|c|c|c|c|c|c|}
\hline & $\begin{array}{l}\text { Sex } \\
(M: F)\end{array}$ & $\begin{array}{l}\text { Race } \\
(B: W)\end{array}$ & $\begin{array}{l}\text { Age } \\
\text { (years) }\end{array}$ & $\begin{array}{l}\text { Body mass } \\
\text { index } \\
\left(\mathrm{kg} / \mathrm{m}^{2}\right)\end{array}$ & $\begin{array}{l}\text { Duration } \\
\text { of diabetes } \\
\text { (years) }\end{array}$ & $\begin{array}{l}\text { Insulin } \\
\text { (U/ kg } \\
\text { body weight) }\end{array}$ \\
\hline $\begin{array}{l}\text { Control } \\
\text { subjects } \\
(n=10) \\
\end{array}$ & $3: 7$ & $1: 9$ & $\begin{array}{l}34.3 \pm 2.5 \\
(25-49)\end{array}$ & $\begin{array}{l}25.0 \pm 1.4 \\
(18.6-35.9)\end{array}$ & - & - \\
\hline$p$ & - & - & $\mathrm{NS}$ & NS & - & - \\
\hline
\end{tabular}

Values expressed as mean \pm SEM (range); $N S=$ not significant

Type 1 diabetic patients have shown an impairment in the uptake and catabolism of this particle by human fibroblasts [15]. However, studies using LDL isolated from Type 2 (non-insulin-dependent) diabetic patients have not documented any abnormality in LDL catabolism by fibroblasts, except in patients who were markedly hypertriglyceridaemic $[16,17]$. LDL glycosylation was not determined in any of the above studies. Since macrophages are thought to be the main precursors of the cholesterol-laden foam cells characteristic of atheromatous lesions $[18,19]$, we decided to investigate the interaction of human monocyte-derived macrophages with LDL isolated from diabetic patients, and to determine whether increased glycosylation of LDL influences this interaction.

\section{Subjects and methods}

Ten patients with Type 1 diabetes, diagnosed according to the criteria established by the National Diabetes Data Group [20], were recruited from the Private Diagnostic Clinic of the Medical University of South Carolina. For every diabetic patient an age-, sex- and racematched non-diabetic control subject was recruited and blood was drawn on the same day from each member of the matched pair. Of the 10 diabetic patients, 8 performed home blood glucose monitoring and were asked to provide measurements of blood glucose taken four times daily (before meals) during the week prior to blood sampling. The mean of these values for each patient was recorded as mean home blood glucose (MHBG). Four patients had evidence of background retinopathy and two had evidence of neuropathy. None of the patients had proteinuria. Two patients were receiving thyroxine therapy for hypothyroidism, but were clinically euthyroid; two control subjects were taking diuretics (furosemide or thiazide) and one control subject was taking a beta-blocking agent. One diabetic patient and her corresponding control subject were in the third trimester of pregnancy. Additional characteristics of the diabetic and control groups, including weight, age, sex, and race distribution, are shown in Table 1.

A 60-ml sample of blood was collected in ethylenediamimetetraacetate (EDTA) $(1 \mathrm{mg} / \mathrm{ml}$ blood) from all subjects after a $12-14 \mathrm{~h}$ fast. This was used to isolate LDL for metabolic studies and determination of LDL glycosylation. Fasting plasma glucose, haemoglobin $A_{1 c}\left(H_{b A_{1 c}}\right)$ and fasting lipid profile were determined in all subjects.

Informed consent, as approved by the Institutional Review Board for Human Research of the Medical University of South Carolina, was obtained from all subjects involved in the study.

\section{Protocol}

Cholesteryl ester (CE) synthesis and CE accumulation were measured in human monocyte-derived macrophages incubated with LDL from diabetic patients and matched control subjects. The amount of LDL from diabetic patients and matched control subjects degraded by macrophages was also determined. For each experiment, the monocytes used were obtained from an individual donor. Different donors were used for different experiments. Matched LDL samples from diabetic patients and control subjects were always studied in the same experiment, and each LDL sample was incubated in duplicate. To compensate for variability between cell batches, the $C E$ synthesis results were expressed as the ratios of values obtained for diabetic and control LDL. LDL samples from four of the diabetic: control pairs were studied in more than one experiment to confirm that the $\mathrm{CE}$ synthesis ratio between diabetic and control subjects remained similar despite differences in cell batches.

CE synthesis by macrophages exposed to LDL glycosylated in vitro was also determined using a similar protocol.

Lipid composition (free and esterified cholesterol, triglycerides and phospholipids) and degree of glycosylation were measured in each LDL sample.

\section{Monocyte isolation and maturation}

Monocytes were isolated from leukapheresis specimens by countercurrent centrifugal elutriation [21, 22]. The purity of the monocyte preparations was found to be $93 \%$ by checking morphology on Wright's stained cytocentrifuge preparations, $92 \%$ by nonspecific esterase staining and $93 \%$ by observing their ability to ingest latex particles [23]. The average viability of the cells was $99 \%$. The isolated monocytes were suspended in a specially formulated serum free medium (SFM) to a final concentration of $1 \times 10^{6}$ cells $/ \mathrm{ml}$. The medium was prepared as described [24] using Iscove's modified Dulbecco's medium supplemented with human serum albumin (fatty acid free, $4 \mathrm{mg} / \mathrm{ml}$ ), cholesterol (>99\% pure, $20 \mu \mathrm{g} / \mathrm{ml}$ ), L- $\alpha$-phosphatidylcholine $(80 \mu \mathrm{g} / \mathrm{ml})$, human transferrin $(98 \%$ pure, $1 \mu \mathrm{g} / \mathrm{ml}$ ) (all from Sigma Chemical Company, St. Louis, Mo, USA), human insulin $(0.128 \mathrm{U} / \mathrm{ml}$, Eli Lilly and Co., Indianapolis, Ind, USA), and ferrous chloride $\left(7 \times 10^{-11} \mathrm{~mol} / \mathrm{l}\right.$, Eastman-Kodak, Rochester, NY, USA). Aliquots $(1 \mathrm{ml})$ of the cell suspension were transferred to $35-\mathrm{mm}$ tissue culture dishes and incubated for $2-3 \mathrm{~h}$ at $37^{\circ} \mathrm{C}$ in a humidified incubator $\left(5 \% \mathrm{CO}_{2}\right)$ to allow adherence of the cells. After this time, to induce maturation, the medium was removed and replaced with fresh medium containing $30 \%(\mathrm{~V} / \mathrm{v})$ of whole human serum (Whittaker, M.A. Bioproducts, Walkersville, Md, USA) and the cells were incubated for 8 days at $37^{\circ} \mathrm{C}$. The medium was changed every 3 days. The metabolic experiments were performed using serum free medium prepared as described but without addition of cholesterol.

\section{LDL isolation}

LDL $(1.019<\mathrm{d}<1.063 \mathrm{~g} / \mathrm{ml})$ was isolated from plasma at $15^{\circ} \mathrm{C}$ by sequential ultracentrifugation [25] in a Beckman $50 \mathrm{Ti}$ rotor (Beck- 
man Instruments Inc., Palo Alto, Calif, USA). Salt solutions used to adjust solvent densities contained $0.01 \%$ (w/v) EDTA, pH 7.4. Isolated LDL was washed and concentrated by recentrifugation at the appropriate density in a Beckman SW55 Ti rotor (Beckman Instruments Inc., Palo Alto, Calif, USA). Aliquots of the washed LDL fraction were adjusted to a concentration of $1 \mathrm{mg} / \mathrm{ml}$ and frozen at $-70^{\circ} \mathrm{C}$ for subsequent determination of glycosylation. The LDL preparations were sterilised by passage through a $0.2-\mu \mathrm{m}$ filter (Gelman Sciences, Ann Arbor, Mich, USA) and stored under a nitrogen atmosphere at $4^{\circ} \mathrm{C}$.

\section{In vitro glycosylation of $L D L$}

LDL samples (2 mg protein $/ \mathrm{ml}$ ) from normolipaemic, non-diabetic subjects were incubated under sterile conditions with $90 \mathrm{mmol} / 1 \mathrm{glu}-$ cose, in phosphate buffered saline (PBS), $\mathrm{pH} 7.4$ for 1 week at $37^{\circ} \mathrm{C}$. Glucose was removed by dialysis against saline containing EDTA $(0.01 \%, \mathrm{w} / \mathrm{v})$. A control incubation was performed under the same conditions (including dialysis) but omitting glucose.

\section{Incorporation of $\left[1{ }^{14} \mathrm{C}\right.$-oleate into cholesteryl esters}

Cholesteryl ester synthesis was determined after incubation in duplicate of monocyte-derived macrophages for $20 \mathrm{~h}$, at $37^{\circ} \mathrm{C}$, with serum-free medium (SFM) containing $0.2 \mathrm{mmol}{ }^{14} \mathrm{C}$-oleate $/ 2.5 \mathrm{mg}$ of bovine serum albumine and $100 \mu \mathrm{g}$ of LDL isolated from diabetic patients and matched control subjects. After maturation into macrophages, the cells were washed with sterile phosphate buffered saline (PBS) and received $1 \mathrm{ml}$ of SFM containing ${ }^{14} \mathrm{C}$-oleate complexed with bovine serum albumin [26] and LDL from diabetic patients or control subjects as described above. The cells were incubated for $20 \mathrm{~h}$ at $37^{\circ} \mathrm{C}$ and were harvested with a rubber policeman using $1 \mathrm{ml}$ of PBS and rinsed with $2 \mathrm{ml}$ of the same solution. The harvesting procedure was repeated twice to minimise cell loss. The cells were pelleted by centrifugation ( $1000 \mathrm{~g}$ for $30 \mathrm{~min}$ ), resuspended in $10 \mathrm{ml}$ of PBS and recentrifuged to remove any traces of medium. A lipid extraction of the cell pellet was performed with chloroform/methanol $(2: 1)(\mathrm{v} / \mathrm{v})[27]$. Cholesteryl- $\left[{ }^{14} \mathrm{C}\right]$-oleate was isolated by thin layer chromatography of the lipid extracts on silica gel plates developed in a solvent system of petroleum ether/ethyl ether/acetic acid (80:20: 2) $(v / v / v)$. Lipids were visualised with $I_{2}$ vapor, and the spots which co-migrated with a cholesteryl oleate standard were marked and scraped into scintillation vials after the total disappearance of colour. Scintillation fluid (ScintiPrep, Fisher Scientific Co., Springfield, Fairlawn, NJ, USA), was added and the samples counted in a liquid scintillation counter. Correction for procedural losses was made by adding ${ }^{3} \mathrm{H}$-cholesteryl oleate as an internal standard to the chloroform/methanol extraction mixture. Incorporation of ${ }^{14} \mathrm{C}$ oleate into cholesteryl esters was linear over the period of $20 \mathrm{~h}$. After the lipid extraction, the cell pellet was solubilised with $1 \mathrm{~mol} / 1$ sodium hydroxide $(\mathrm{NaOH})$ and the protein content determined [28].

\section{Measurement of sterol synthesis}

Sterol synthesis was determined by measuring the incorporation of ${ }^{14} \mathrm{C}$ acetate into non-saponifiable sterols [29]. Macrophages were cultured for 8 days in media containing $30 \%$ whole human serum as described before. The media was removed and the cells were washed twice with SFM. Lipoproteins were added to SFM at a concentration of $100 \mu \mathrm{g}$ protein per milliliter media. Additional cultures were maintained in media containing 30\% WHS or SFM without added lipoproteins. All cultures were incubated at $37^{\circ} \mathrm{C}$ for $20 \mathrm{~h}$. Six hours prior to the end of the incubation period, $2-\left[{ }^{14} \mathrm{C}\right]$ acetate $(142 \mu \mathrm{mol} / \mathrm{l}$; $56 \mathrm{mCi} / \mathrm{mmol}$ ) (Amersham Corporation, Arlington Heights, Ill, USA) [29] was added. At the end of the incubation, the medium was removed and the cells were washed twice with PBS. The lipids were extracted into hexane/isopropanol $(3: 2, \mathrm{v} / \mathrm{v})$ [30] containing ${ }^{3} \mathrm{H}$-cholesteryl oleate as an internal standard to correct for procedural losses. The solvents were evaporated to dryness under a nitrogen stream. The lipids were saponified with $1 \mathrm{~mol} / 1$ potassium hydroxide $(\mathrm{KOH})$ in $95 \%$ ethanol for $1 \mathrm{~h}$ at $85^{\circ} \mathrm{C}$. Non-saponifiable lipids were extracted into hexane containing non-radiolabeled cholesterol ( $200 \mu \mathrm{g} /$ extraction). Aliquots of the hexane extracts were removed and evaporated under a nitrogen stream. The lipid residue was dissolved in acetone/diethyl ether $(1: 1, \mathrm{v} / \mathrm{v})$, acidified with $10 \%$ acetic acid and the sterols were precipitated with $0.5 \%$ digitonin. The precipitate was left to stand overnight at $4^{\circ} \mathrm{C}$ and then was washed three times, once with acetone/diethyl ether $(1: 2, \mathrm{v} / \mathrm{v})$ and then twice with diethyl ether. The precipitate was dried under a stream of air, dissolved in $500 \mu \mathrm{l}$ concentrated glacial acetic acid and a $400 \mu \mathrm{l}$ aliquot was taken for liquid scintillation counting in ACS II (Amersham). The yields of products were calculated from the specific activities of the substrates and on the assumption that all radiolabel was incorporated into $\mathrm{C}_{27}$ sterols which contained 15 labelled positions derived from $\left[2 \cdot{ }^{14} \mathrm{C}\right]$-acetate.

\section{Measurement of free and esterified cholesterol content in macrophages}

To perform these experiments, $3 \times 10^{6}$ monocytes per culture dish were plated and matured into macrophages as described above. After maturation into macrophages, the medium was removed and the cells were washed with PBS to remove any trace of medium containing whole human serum. SFM containing $100 \mu \mathrm{g} / \mathrm{ml}$ of LDL isolated from control subjects or diabetic patients was added to each culture and the cells were then incubated for $20 \mathrm{~h}$. After the incubation, the medium was removed and the cells were harvested as described above. The cell pellet was extracted with chloroform/methanol $(2: 1)(v / v)$ as previously described [27]. Free and total cholesterol in cell lipid extracts were assayed on a gas-chromatograph equipped with a hydrogen flame ionization detector. A glass column packed with 3\% SP-2250 on 80/100 mesh Supelcoport (Supelco, Inc. Belleforte, Penn, USA) was used for the chromatographic separation and its temperature maintained at $250^{\circ} \mathrm{C}$ during the separation. Nitrogen was used as the carrier gas. For assay of total cholesterol, the chloroform extracts were evaporated to dryness and the residue hydrolysed by Ishikawa's method [31] as previously described [15]. Cholesteryl ester levels were obtained by subtracting free cholesterol from total cholesterol levels. $5 \alpha$-cholestane was used as internal standard.

\section{LDL degradation studies}

After appropriate labelling with ${ }^{125} \mathrm{I}$ [15], LDL from each diabetic patient and matched control subject was added to $1 \times 10^{6}$ macrophages, at three different concentrations $(20,100$ and $250 \mu \mathrm{g} / \mathrm{ml})$ and incubated for $20 \mathrm{~h}$, at $37^{\circ} \mathrm{C}$. After the incubation, the medium was removed and used to measure LDL degradation. The cells were then washed two times with $1 \mathrm{ml}$ PBS containing $0.2 \%(\mathrm{w} / \mathrm{v})$ bovine serum albumin followed by two additional washes with PBS without albumin. Afterwards, the cells were dissolved in $1 \mathrm{~mol} / 1 \mathrm{NaOH}$ and used to determine the amount of cellular protein.

The proteolytic degradation of ${ }^{125}$ I-labelled lipoproteins by human macrophages was measured by assaying the amount of ${ }^{125} \mathrm{I}$ trichloroacetic acid (TCA)-soluble (non-iodide) material formed by the cells and excreted into the culture medium [32]. Receptor-mediated degradation was determined as the difference between degradation levels in cells incubated with only ${ }^{125} \mathrm{I}-\mathrm{LDL}$ and parallel incubations containing ${ }^{125} \mathrm{I}$-LDL and a 25 -fold excess of unlabelled LDL. Corrections were made for the small amounts of ${ }^{125}$ I-labelled acidsoluble material that was found in parallel incubations without cells. Prior to the addition of lipoproteins, the cells were incubated for $24 \mathrm{~h}$ with lipoprotein deficient serum (LPDS) $(5 \mathrm{mg}$ of protein $/ \mathrm{ml}$ of medium). 
Table 2. Parameters of glycaemic control and plasma lipid levels in diabetic and control groups

\begin{tabular}{|c|c|c|c|c|c|c|c|c|c|}
\hline & $\begin{array}{l}{ }^{a} \mathrm{FPG} \\
(\mathrm{mmol} / 1)\end{array}$ & $\begin{array}{l}{ }^{\mathrm{b}} \mathrm{MHBG} \\
(\mathrm{mmol} / \mathrm{l})\end{array}$ & $\begin{array}{l}{ }^{\mathrm{c}} \mathrm{HbA}_{1 \mathrm{c}} \\
(\%)\end{array}$ & $\begin{array}{l}{ }^{d} \text { Gly-LDL } \\
{ }^{3} \mathrm{H}-\mathrm{HAA} \\
\mathrm{cpm} / \mathrm{\mu g}\end{array}$ & $\begin{array}{l}\text { Total } \\
{ }^{e} \mathrm{Chol} \\
(\mathrm{mmol} / \mathrm{l})\end{array}$ & $\begin{array}{l}{ }^{\mathrm{f}} \mathrm{TG} \\
(\mathrm{mmol} / \mathrm{l})\end{array}$ & $\begin{array}{l}\text { gVLDL } \\
\text { Chol } \\
(\mathrm{mmol} / \mathrm{l})\end{array}$ & $\begin{array}{l}{ }^{h} \mathrm{LDL} \\
\text { Chol } \\
(\mathrm{mmol} / \mathrm{l})\end{array}$ & $\begin{array}{l}{ }^{\mathrm{i}} \mathrm{HDL} \\
\mathrm{Chol} \\
(\mathrm{mmol} / \mathrm{l})\end{array}$ \\
\hline $\begin{array}{l}\text { Controls } \\
\text { subjects } \\
(n=10)\end{array}$ & $\begin{array}{l}4.7 \pm 0.16 \\
(4.2-5.6)\end{array}$ & - & $\begin{array}{l}5.6 \pm 0.1 \\
(5.4-6.0)\end{array}$ & $\begin{array}{l}22.4 \pm 1.3 \\
(18.1-30.5)\end{array}$ & $\begin{array}{l}5.0 \pm 0.28 \\
(4.3-7.2)\end{array}$ & $\begin{array}{c}1.33 \pm 0.21 \\
(0.76-2.83)\end{array}$ & $\begin{array}{l}0.69 \pm 0.16 \\
(0.18-1.81)\end{array}$ & $\begin{array}{l}3.2 \pm 0.21 \\
(2.43-4.24)\end{array}$ & $\begin{array}{c}1.24 \pm 0.78 \\
(0.88-1.76)\end{array}$ \\
\hline$p$ & $<0.01$ & & $<0.001$ & $<0.01$ & NS & NS & NS & NS & NS \\
\hline
\end{tabular}

${ }^{a}$ Fasting plasma glucose $;{ }^{b}$ mean home blood glucose; ${ }^{c}$ haemoglobin $\mathrm{A}_{1 \mathrm{c}}$ fraction; ${ }^{\mathrm{d}}$ glycosylated LDL, ${ }^{3} \mathrm{H}$-HAA $=$ tritiated hexitol-amino-acid; ${ }^{\mathrm{e}}$ cholesterol; ${ }^{\mathrm{f}}$ triglycerides; ${ }^{\mathrm{g}}$ very low-density lipoproteins; ${ }^{\mathrm{h}}$ low density lipoproteins; ${ }^{\mathrm{i}}$ high density lipoproteins. ${ }^{j}$ MHBG was obtained from eight patients only. They reported an average of 24 blood glucose readings in 7 days. Values shown indicate mean $\pm S E M$ (range). NS $=$ not significant

Table 3. Chemical composition of LDL from diabetic patients and control subjects

\begin{tabular}{|c|c|c|c|c|c|c|c|c|c|}
\hline \multirow[t]{2}{*}{ Subjects } & \multicolumn{5}{|c|}{ Percent by weight } & \multicolumn{4}{|c|}{ Ratios of constituents ( $\mu \mathrm{mol} / \mathrm{mg}$ protein) } \\
\hline & Pro & FC & CE & TG & PL & $\mathrm{FC}$ & $\mathrm{CE}$ & TG & PL \\
\hline Control & $19.6^{\mathrm{a}}$ & 10.1 & 43.9 & 6.2 & 20.3 & 1.33 & 3.35 & 0.36 & 1.33 \\
\hline \multirow[t]{2}{*}{ Diabetic } & 19.0 & 10.4 & 43.9 & 5.7 & 21.0 & 1.42 & 3.46 & 0.34 & 1.42 \\
\hline & \pm 0.9 & \pm 0.4 & \pm 0.6 & \pm 0.6 & \pm 1.0 & \pm 0.16 & \pm 0.33 & \pm 0.04 & \pm 0.09 \\
\hline
\end{tabular}

${ }^{a}$ Mean \pm SEM, $n=10$. Pro: protein; FC: free cholesterol; CE: cholesteryl ester=esterified cholesterol X 1.7; TG: triglyceride; PL: phospholipid. Molecular weights assumed: $\mathrm{FC}=386.6, \mathrm{CE}=668, \mathrm{TG}=885.4, \mathrm{PL}=778.2$

\section{Determination of LDL composition}

Samples of isolated LDL were extracted with chloroform/methanol $(2: 1)(v: v)[27]$. Their free and total cholesterol contents were determined by gas chromatography, as described above for cellular cholesterol mass determination.

The triglyceride content of isolated LDL was measured using a semiautomated method standardised by the Lipid Research Clinics Program [33]. The phosphorus content of phospholipids was assayed by the method of Barlett et al. [34]. Protein was determined by the Lowry method [28], using bovine serum albumin (Sigma) as a standard.

\section{Measurement of glycosylation of $L D L$}

Glycosylation of LDL was determined by affinity chromatography, using a method recently described by us [35], which is similar to that employed by Yue et al. [36] in the measurement of tissue protein glycosylation. Stored LDL samples were thawed and aggregated lipoproteins were dispersed by brief $(<5 \mathrm{~s}$ ) sonication (Probe sonicator, Heat Systems-Ultrasonic Inc., Plainview, NY, USA) before assessing their degree of glycosylation.

The extent of glycosylation of LDL was expressed as ${ }^{3} \mathrm{H}$-hexitolaminoacid radioactivity counts per $\mu \mathrm{g}$ LDL. The results presented in this paper were obtained from three separate experiments conducted during the same week. In every case both members of a diabetic-control pair were studied in the same experiment, and the same batch of tritiated sodium borohydride was used throughout. The between-assay coefficient of variation for the whole procedure was $10.8 \%$ $(n=6)$, and the within-assay variation, $7.8 \%$.

\section{Other methods}

Home plasma glucose measurements were obtained and recorded by the patients using Dextrostix and a Glucometer (Ames Division,
Miles Laboratories Inc., Elkhart, Ind, USA). Plasma glucose was assayed by the glucose oxidase method, as adapted for use in the Beckman glucose analyser [37]. $\mathrm{HbA}_{1 \mathrm{c}}$ was measured by isoelectric focusing of erythrocyte haemolysates in a gradient of $\mathrm{pH} 6-8$ [38].

Separation of lipoproteins was performed by ultracentrifugation as previously described [15]. High-density lipoproteins (HDL) were isolated from whole plasma by precipitating very low density lipoproteins (VLDL) and LDL with sodium phosphotungstate/magnesium chloride, as described [39]. Total cholesterol and triglyceride were measured in whole plasma and lipoprotein fractions by the semi-automated methods standardised by the Lipid Research Clinics Program [33].

\section{Statistical analysis}

Statistical analysis was performed using the mean paired Student's ttest and the Wilcoxon signed rank test to compare differences between paired data. Correlation coefficients were determined by linear regression analysis. All results are expressed as mean \pm SEM.

\section{Results}

LDL from hyperglycaemic, normolipaemic diabetic patients (see Table 2) stimulated significantly more CE synthesis than LDL from control subjects $(7.19 \pm 1.19$ vs $6.11 \pm 0.94 \mathrm{nmol}{ }^{14} \mathrm{C}$-cholesteryl oleate per mg cell protein per $20 \mathrm{~h}, p<0.05$ ). In order to determine whether changes in LDL lipid composition might be responsible for this increase, we measured cholesterol (free and esterified), triglycerides, phospholipids and total protein in the LDL from diabetic patients and control subjects. As shown in Table 3, no significant 


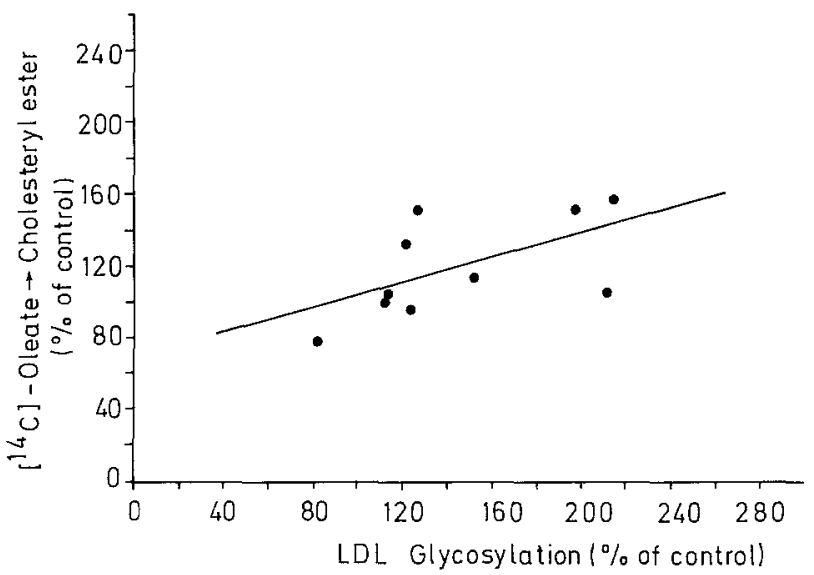

Fig. 1. Relationship in 10 diabetic patients between LDL glycosylation and cholesteryl ester synthesis by macrophages. LDL glycosylation and cholesteryl ester synthesis for each diabetic patient is expressed as a percentage of the level determined in incubations with LDL isolated from the corresponding control subject. Cholesteryl ester synthesis rates in control subjects averaged $6.1 \pm 0.9 \mathrm{nmol}$ ${ }^{14} \mathrm{C}$-cholesteryl oleate synthesised per mg cell protein per $20 \mathrm{~h}$. $(y=69.8+0.34 \mathrm{X}, r=0.58, p<0.05)$

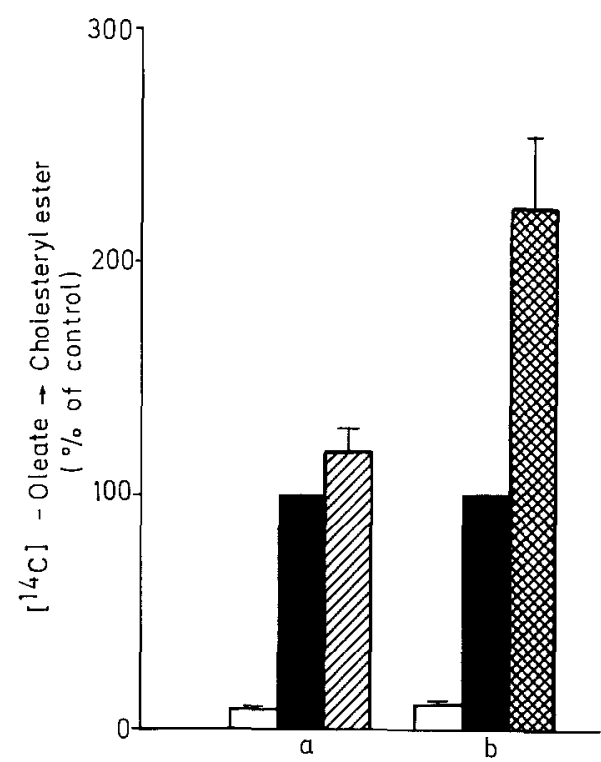

Fig. 2. Rates of synthesis of ${ }^{14} \mathrm{C}$-cholesteryl oleate by macrophages incubated with (a) $\mathrm{LDL}(100 \mu \mathrm{g} / \mathrm{ml})$ isolated from 10 diabetic patients $\nabla$ and 10 control subjects $\boldsymbol{\omega}$ and with $(b)$ in vitro glycosylated and control $\mathbf{D D L}(100 \mu \mathrm{g} / \mathrm{ml})$. Rates of cholesteryl ester synthesis are expressed as a percentage of the rate determined in cells incubated with control LDL with this rate set equal to 100 . Absolute rates of cholesteryl ester synthesis in macrophages incubated with control LDL averaged $6.1 \pm 0.9$ and $4.8 \pm 0.1 \mathrm{nmol}{ }^{14} \mathrm{C}$-cholesteryl oleate synthesised per $\mathrm{mg}$ cell protein per $20 \mathrm{~h}$ for the experiments in $a$ and $b$ respectively. The rate of cholesteryl ester synthesis by cells not incubated with LDL $\square$ averaged $8.6 \pm 1.1 \%$ of the level determined in incubations with control LDL

differences were found in the lipid composition of LDL isolated from the two groups. Therefore we proceeded to investigate whether abnormalities in apolipoprotein $\mathrm{B}$ could be responsible for the increase in $\mathrm{CE}$ synthesis observed.
Table 4. Cellular accumulation of free, esterified and total cholesterol in human macrophages

\begin{tabular}{llcl}
\hline Incubation & \multicolumn{3}{l}{$\begin{array}{l}\text { Cellular cholesterol mass } \\
\text { (nmol/mg cell protein) }\end{array}$} \\
\cline { 2 - 4 } & Free & Esterified & Total \\
\hline No lipoprotein & $106 \pm 4^{\mathrm{a}}$ & $10 \pm 1$ & $116 \pm 3$ \\
Control LDL & $115 \pm 10^{\mathrm{b}}$ & $20 \pm 3$ & $135 \pm 11$ \\
Diabetic LDL & $119 \pm 11^{\mathrm{b}}$ & $25 \pm 2^{\mathrm{c}}$ & $143 \pm 10^{\mathrm{d}}$ \\
Acetyl LDL & $122 \pm 10^{\mathrm{a}}$ & $111 \pm 21$ & $233 \pm 19$ \\
\hline
\end{tabular}

a Mean $\pm S E M$, triplicate incubations with macrophages from three different donors. ${ }^{b}$ Mean \pm SEM of seven of the ten pairs of subjects incubated in duplicate with macrophages from four different donors. ${ }^{c} p<0.02$ vs control LDL. ${ }^{d} p<0.05$ vs control LDL

We found, as shown in Table 2, that the degree of glycosylation of LDL from diabetic patients was increased 1.4-fold over control values $(p<0.01)$ and that a significant correlation was present between LDL glycosylation and CE synthesis $(n=10, r=0.58, p<0.05)$ (Fig.1). Since glycosylation of LDL was found to correlate significantly with mean home blood glucose (MHBG) $(n=8, r=0.76, p<0.05)$ but not with $\mathrm{HbA}_{10}$ ( $n=10, r=0.38$, NS), we assessed the relationship between these two parameters and CE synthesis. A significant correlation was found between MHBG and CE synthesis $(n=8, r=0.67, p<0.05)$, but as expected there was no correlation between $\mathrm{HbA}_{1 \mathrm{c}}$ and $\mathrm{CE}$ synthesis.

To further investigate the role played by LDL glycosylation, we measured $\mathrm{CE}$ synthesis in human macrophages incubated with LDL glycosylated in vitro. Like LDL from diabetic patients, LDL glycosylated in vitro stimulated significantly more $\mathrm{CE}$ synthesis than control LDL $\left(10.65 \pm 1.50\right.$ vs $4.80 \pm 0.13 \mathrm{nmol}{ }^{14} \mathrm{C}$-cholesteryl oleate per mg cell protein per $20 \mathrm{~h}, p<0.05$ ) (Fig. 2). However, the LDL glycosylated in vitro stimulated a greater increase in $C E$ synthesis than that observed with LDL from diabetic patients (Fig. 2). This was expected, since previous studies in this laboratory have shown that, using the conditions described in methods for LDL glycosylation, we obtain, on average, a four-fold increase in LDL glycosylation. That degree of glycosylation is greater than that found in the LDL of the diabetic patients we studied.

To determine whether the enhancement in CE synthesis by macrophages exposed to LDL from diabetic patients was paralleled by intracellular accumulation of cholesteryl esters we determined the cholesterol content (free and esterified) of macrophages exposed for $20 \mathrm{~h}$ to $\mathrm{LDL}$ isolated from diabetic patients and matched control subjects. There was a significantly increased accumulation of total and esterified cholesterol in the cells exposed to LDL isolated from diabetic patients $(p<0.02)$ (Table 4). No difference was found in the free cholesterol content of cells exposed to LDL from diabetic patients and control subjects. 
Table 5. Incorporation of $2-{ }^{14} \mathrm{C}$-acetate into digitonin precipitable sterols by human macrophages incubated with low density lipoproteins isolated from diabetic patients and control subjects

\begin{tabular}{ll}
\hline Culture media addition & Sterol synthesis (pmol/mg cell protein) \\
\hline SFM alone & $281.1 \pm 53.9$ \\
Control LDL & $123.7 \pm 13.0$ \\
Diabetic LDL & $106.3 \pm 3.7$ \\
$30 \%$ WHS & $41.2 \pm 2.1$
\end{tabular}

Cells were incubated for $14 \mathrm{~h}$ in Serum free medium (SFM) containing isolated $\mathrm{LDL}(100 \mathrm{\mu g} / \mathrm{ml})$ or $30 \%$ whole human serum (WHS). After this preincubation, $2{ }^{14} \mathrm{C}$-acetate was added to each culture and the incubation continued for an additional $6 \mathrm{~h}$. Cellular lipids were extracted and the incorporation of $2-{ }^{14} \mathrm{C}$-acetate into nonsaponifiable, digitonin precipitable sterols was determined as described in Methods. Values are mean $\pm \mathrm{SD}$ of four determinations

Table 6. Degradation by human macrophages of ${ }^{125}$ I-labelled LDL isolated from control subjects (control LDL) and diabetic patients (diabetic LDL)

\begin{tabular}{lrr}
\hline & \multicolumn{1}{c}{$\begin{array}{l}\text { Control } \\
\text { LDL }\end{array}$} & \multicolumn{1}{c}{$\begin{array}{l}\text { Diabetic } \\
\text { LDL }\end{array}$} \\
\hline $\begin{array}{l}\text { Total degradation } \\
\text { (ng LDL/mg cell protein) }\end{array}$ & & \\
$20 \mu \mathrm{g} \mathrm{LDL} / \mathrm{ml}$ medium & $2,982 \pm 72$ & $3,542 \pm 225$ \\
$100 \mu \mathrm{g} \mathrm{LDL} / \mathrm{ml}$ medium & $6,946 \pm 635$ & $7,860 \pm 426$ \\
$250 \mu \mathrm{g}$ LDL/ml medium & $10,558 \pm 774$ & $11,109 \pm 602$ \\
$\begin{array}{l}\text { Non-high-affinity receptor } \\
\text { mediated degradation }\end{array}$ & & \\
(ng LDL/mg cell protein) & & \\
$\quad 80 \mu \mathrm{g}$ LDL/ml medium & $578 \pm 38$ & $639 \pm 24$ \\
$100 \mu \mathrm{g} \mathrm{LDL} / \mathrm{ml}$ medium & $1,245 \pm 70$ & $1,327 \pm 96$ \\
\hline
\end{tabular}

The above levels were determined in 5 of the 10 diabetic: control pairs studied. a Degradation of ${ }^{125}$ I-LDL by macrophages incubated with the indicated amounts of ${ }^{125}$ I-LDL plus a 25 -fold excess of unlabelled lipoprotein

We determined the effects on macrophage sterol synthesis of LDL isolated from diabetic patients and control subjects by measuring the incorporation of ${ }^{14} \mathrm{C}$ acetate into macrophage non-saponifiable, digitonin precipitable sterols (Table 5). The incorporation of ${ }^{14} \mathrm{C}$ acetate into macrophage sterols was determined as described in Methods. LDL pooled from two diabetic patients and from two nondiabetic, matched control subjects was used to perform the experiments. As expected, macrophages which were up-regulated by incubation for $20 \mathrm{~h}$ in SFM incorporated significantly more ${ }^{14} \mathrm{C}$-acetate into sterols than did cells incubated with isolated LDL or whole human serum. Macrophages incubated with LDL isolated from diabetic patients incorporated significantly less ${ }^{14} \mathrm{C}$-acetate into sterols than did cells incubated with isolated LDL from control subjects (Table 5).

To determine if the observed increase in CE synthesis and accumulation resulted from an increased degradation by macrophages of LDL isolated from diabetic patients, we compared the degradation of ${ }^{125} \mathrm{I}-\mathrm{LDL}$ from control subjects and diabetic patients. There was no significant difference between the receptor-mediat- ed degradation of LDL isolated from control subjects and diabetic patients. In contrast, there was a significant increase in the total and non-high affinity receptor mediated degradation (nonspecific degradation = totalreceptor mediated degradation) of the LDL from diabetic patients compared to that isolated from control subjects $(p<0.05)$ when ${ }^{125} \mathrm{I}$-LDL was included at concentrations of 20 and $100 \mu \mathrm{g} \mathrm{LDL} / \mathrm{ml}$ in the medium (Table 6).

\section{Discussion}

In the present study, human macrophages exposed to LDL isolated from normolipaemic, Type 1 diabetic patients showed enhanced CE synthesis. Furthermore, the enhancement in $\mathrm{CE}$ synthesis was significantly correlated with the degree of glycosylation of LDL. This suggests that glycosylation of LDL may be responsible for the increase in CE synthesis, and this hypothesis is supported by our findings using LDL glycosylated in vitro. Here, LDL glycosylation was increased four-fold over control values, and was therefore higher than that found in our patients. This degree of glycosylation stimulated a two-fold increase in $\mathrm{CE}$ synthesis, which is in close agreement with the value predicted by the regression line in Figure 1. Furthermore, the increase in CE synthesis observed was accompanied by increased intracellular accumulation of CE.

These results are of interest because they suggest the presence of an abnormality of lipoprotein metabolism in diabetes, even in patients who are in relatively good glycaemic control and whose plasma lipid and lipoprotein levels are normal. Epidemiological studies have shown that the diabetic state, in itself and independent of all other recognised risk factors, is associated with a higher incidence of atherosclerosis [40, 41]. Our findings suggest that this independent risk factor may result, at least in part, from abnormal interactions between glycosylated LDL and macrophages in the arterial wall.

The mechanism(s) responsible for the enhancement of CE synthesis and accumulation in macrophages exposed to LDL from diabetic patients may derive from the observed increase in the total degradation of LDL isolated from diabetic patients. It appears that the increase in total degradation of glycosylated LDL and of LDL isolated from diabetic patients is due to their increased uptake by a pathway independent of the classical LDL receptor pathway. Studies performed in our laboratory using LDL glycosylated in vitro favour this hypothesis since they also show an increased degradation of the glycosylated lipoprotein by macrophages [42]. Whether the recognition of glycosylated LDL or LDL from diabetic patients is mediated by a nonspecific pathway or by a low affinity pathway needs to be determined. 
Although our findings have clearly demonstrated the importance of glycosylation in inducing an abnormal LDL-macrophage interaction, increased glycosylation is not the only possible mechanism to explain abnormal LDL-macrophage interactions in diabetes. In this study, the diabetic patients were in good glycaemic control and the lipid composition of LDL isolated from diabetic patients was similar to that of LDL from non-diabetic control subjects. However, in poorly-controlled patients, alterations in LDL composition such as increased triglyceride content may also be involved. Lopes-Virella et al. [15] have previously shown that the recognition by fibroblasts of triglyceride-enriched LDL, isolated from poorly controlled Type 1 diabetic patients was impaired. However, Kraemer et al. [16], studying LDL from patients with Type 2 diabetes, which again was triglyceride-enriched, found no alteration in binding or degradation by fibroblasts or by mouse peritoneal macrophages. In neither of these studies was the extent of glycosylation of LDL measured nor was the possible role of triglyceride-enrichment of LDL in altering its behaviour assessed. Hiramatsu et al. [17] in a later study showed that triglyceride-enriched LDL, isolated from both diabetic and non-diabetic patients with marked hypertriglyceridaemia, was poorly recognised by fibroblasts. Another lipoprotein modification which may be important in diabetes is that due to oxidation of lipoprotein lipids resulting from prolonged circulation times. Increased levels of oxidised lipoproteins have been reported in diabetic animals [43] and in human diabetic patients [44]. The significance of these findings in not clear; however, such modifications could potentially lead to increased lipoprotein uptake by the scavenger pathway and lead to increased intracellular CE accumulation. It is therefore possible that functional abnormalities of LDL in diabetes may be induced not only by modifications (glycosylation or oxidation) of the apoprotein moiety but also by abnormalities in the lipid moiety of the particle. It would be of interest to determine whether abnormalities induced by these different processes are additive and to compare the interaction of these abnormal LDL particles with different cell types.

In the present study the increase in CE synthesis and accumulation by human macrophages exposed to LDL from diabetic patients was relatively small. However, since it was observed with LDL from patients in good or fair glycaemic control, it is likely to be a constant process and present in almost all diabetic patients. Therefore, it may lead to serious long-term consequences by accelerating the development of macrovascular complications. The data provide further evidence that "tight" glycaemic control is an important goal in the management of diabetes.

Acknowledgements. The authors wish to thank Drs. J.A.Colwell and R.K. Mayfield for their assistance in patient recruitment, and for permission to study patients under their care. They also acknowledge the cooperation and assistance of the staff of the General Clini- cal Research Center, Medical University of South Carolina, Charleston, and of the Special Diagnostic and Treatment Unit, Veterans Administration Medical Center, Charleston. Expert laboratory assistance was provided by Mr. L. Long and Ms V.Waldrop, Charleston and Dr. S. Thorpe and Mr. J. Patrick, University of South Carolina, Columbia. Secretarial assistance was provided by Ms E. Katko. This work was supported by the Research Service of the Veterans Administration and by the National Institutes of Health Grant HL 30929.

\section{References}

1. West KM (1982) Hyperglycaemia as a cause of long-term complications. In: Keen H, Jarrett RJ (eds) Complications of diabetes. Edward Arnold, London, pp 13-18

2. Nomenclature Committee of IUB, Joint Commission on Biochemical Nomenclature, Newsletter (1984) Biochem J 217: I-IV

3. Gottshalk A (1972) Interaction between reducing sugars and amino-acids under neutral and acidic conditions. In: Gottshalk A (ed) Glycoproteins. Elsevier, Amsterdam, pp 141-157

4. Kennedy L, Baynes JW (1984) Nonenzymatic glycosylation and the chronic complications of diabetes: an overview. Diabetologa $26: 93-98$

5. Monnier VM, Cerami A (1981) Non-enzymatic browning in vivo. Possible process for aging of long-lived proteins. Science 211: 491-493

6. Monnier VM, Stevens VJ, Cerami A (1979) Non-enzymatic glycosylation, sulfhydryl oxidation and aggregation of lens protein in experimental sugar cataracts. J Exp Med 150: 1098-1107

7. Yue DK, McLennan S, Delbridge L, Handelsman DJ, Reeve T, Turtle JR (1983) The thermal stability of collagen in diabetic rats: correlation with severity of diabetes and nonenzymatic glycosylation. Diabetologia 24: 282-285

8. Kent MJC, Light ND, Bailey AJ (1985) Evidence for glucosemediated covalent cross-linking of collagen after glycosylation in vitro. Biochem J 225: 745-752

9. Gonen B, Baenziger J, Schonfeld G, Jacobson D, Farrar P (1981) Nonenzymatic glycosylation of low density lipoproteins in vitro. Diabetes 30: 875-878

10. Witztum JL, Mahoney EM, Branks MJ, Fisher M, Elam R, Steinberg D (1982) Nonenzymatic glucosylation of low density lipoprotein alters its biologic activity. Diabetes 31: 283-291

11. Kannel WB, McGee DL (1979) Diabetes and cardiovascular disease. The Framingham Study. JAMA 241: 2035-2038

12. Curtiss LK, Witztum JL (1985) Plasma apolipoproteins AI, AII, $\mathrm{B}, \mathrm{CI}$ and $\mathrm{E}$ are glucosylated in hyperglycemic diabetic subjects. Diabetes 34: 452-461

13. Sasaki J, Cottam GL (1982) Glycosylation of LDL decreases its ability to interact with high affinity receptors of human fibroblasts in vitro and decreases its clearance from rabbit plasma in vivo. Biochim Biophys Acta 713: 199-207

14. Steinbrecher UP, Witztum JL (1984) Glucosylation of low density lipoproteins to an extent comparable to that seen in diabetes slows their catabolism. Diabetes 33: 130-134

15. Lopes-Virella MF, Sherer GK, Lees AM, Wohltmann H, Mayfield R, Sagel J, LeRoy EC, Colwell JA (1982) Surface binding, internalisation and degradation by cultured human fibroblasts of low density lipoproteins isolated from Type 1 (insulin-dependent) diabetic patients: changes with metabolic control. Diabetologia 22: 430-436

16. Kraemer FB, Chen Y-DI, Cheung RMC, Reaven GM (1982) Are the binding and degradation of low density lipoprotein altered in Type 2 (non-insulin-dependent) diabetes mellitus? Diabetologia $23: 28-33$

17. Hiramatsu K, Bierman EL, Chait A (1985) Metabolism of low density lipoprotein from patients with diabetic hypertriglyceridemia by cultured human skin fibroblasts. Diabetes $34: 8-14$

18. Ross R (1981) Atherosclerosis: a problem of the biology of the arterial wall cells and their interaction with blood components. Arteriosclerosis 1: 293-311 
19. Pitas RE, Innerarity TL, Mahley RB (1981) Foam cells in explants of atherosclerotic rabbit aortas have receptors for $\beta$-very low density lipoproteins and modified low density lipoproteins. Arteriosclerosis 3: 1-12

20. National Diabetes Data Group (1979) Classification and diagnosis of diabetes mellitus and other categories of glucose intolerance. Diabetes 28: 1039-1057

21. Stevenson HC, Beman JA, Oldham RK (1983) Design of a cancer immunology cytapheresis unit. Plasma Ther 4: 57-63

22. Stevenson HC (1985) Separation of mononuclear leukocyte subsets by counter current centrifugation elutriation. In: Gisabato G, Langone $T$, von Vunakis $H$ (eds) Methods in enzymology: immunochemical techniques, Part G. Academic, New York, pp 242-249

23. Stevenson HC, Katz P, Wright DG, Contreras TJ, Jemionek JF, Hartwig VM, Flor WJ, Fauci AS (1981) Human blood monocytes: characterization of the negatively selected human monocyte and their suspension cell culture derivatives. Scand J Immunol 14: 243-256

24. Stevenson HC, Miller P, Akiyama Y, Favilla T, Beman JA, Herberman R, Stull H, Thurman G, Maluish A, Oldham R (1983) A system for obtaining large numbers of cryopreserved human monocytes purified by leukapheresis and counter-current centrifugation elutriation. J Immunol Methods 62: 353-363

25. Havel RJ, Eder HA, Bragdon JH (1955) The distribution and chemical composition of ultracentrifugally separated lipoproteins in human serum. J Clin Invest 34: 1345-1353

26. Goldstein JL, Dana SE, Brown MS (1974) Esterification of low density lipoprotein cholesterol in human fibroblasts and its absence in homozygous familial hypercholesterolemia. Proc Natl Acad Sci USA 71: 4288-4292

27. Folch J, Lees M, Stanley GHS (1957) A simple method for the isolation and purification of total lipids from animal tissues. $\mathrm{J}$ Biol Chem 226: 497-509

28. Lowry OH, Rosebrough NJ, Farr AL, Randall BJ (1951) Protein measurement with the Folin phenol reagent. J Biol Chem 193: 265-275

29. Chait A, Eisenberg S, Steinmetz A, Albers JJ, Bierman EL (1984) Low density lipoproteins modified by lipid transfer protein have altered biological activity. Biochim Biophys Acta 795: 314-325

30. Goldstein JL, Brown MS (1977) The low-density lipoprotein pathway and its relation to atherosclerosis. Ann Rev Biochem 46: 897-930

31. Ishikawa TT, McGee Y, Morrison JA, Glueck CJ (1974) Quantitative analyses of cholesterol in 5 to $20 \mu \mathrm{l}$ of plasma. J Lipid Res 15: 286-291

32. Bierman EL, Stein O, Stein Y (1979) Lipoprotein uptake and me- tabolism by rat aortic smooth muscle cells in tissue culture. Circ Res 35: 136-150

33. Manual of Lipid Operations (1974) Lipid Research Clinics Program, Vol 1. Lipid and Lipoprotein Analysis. Department of Health, Education and Welfare, Publ No (NIH) 75-628

34. Bartlett GR (1959) Phosphorus assay in column chromatography. J Biol Chem 234: 466-468

35. Lyons TJ, Baynes JW, Patrick JS, Colwell JA, Lopes-Virella MF (1986) Glycosylation of LDL in patients with Type 1 (insulin-dependent) diabetes: correlations with other parameters of glycaemic control. Diabetologia 29: 685-689

36. Yue DK, McLennan S, Turtle JR (1981) Non-enzymatic glycosylation of tissue protein in diabetes in the rat. Diabetologia 24: 377-381

37. Kadish AH, Little RL, Steinberg JC (1986) A new and rapid method for the determination of glucose by measurement of rate of oxygen consumption. Clin Chem 14: 116-131

38. Spicer KN, Allen RC, Buse MG (1978) A simplified assay of hemoglobin $A_{1 c}$ in diabetic patients, using isoelectric focusing and quantitative microdensitometry. Diabetes $27: 384-388$

39. Lopes-Virella MF, Stone P, Ellis S, Colwell JA (1977) Cholesterol determination in high density lipoproteins separated by three different methods. Clin Chem 23: 882-884

40. Garcia MJ, McNamara PM, Gordon T, Kannell WB (1974) Morbidity and mortality in diabetics in the Framingham population. Diabetes 23: 105-111

41. Gordon T, Castelli WP, Hjortland MC, Kannel WB, Dawber TR (1977) Diabetes, blood lipids and the role of obesity in coronary heart disease risk for women. Ann Intern Med 87: 393-397

42. Lopes-Virella MF, Klein RL, Lyons TJ, Stevenson HC, Witztum JL (1988) Glycosylation of low density lipoprotein enhances cholesteryl ester synthesis in human monocyte-derived macrophages. Diabetes 37 (in press)

43. Higuchi Y (1982) Lipid peroxides and $\gamma$-tocopherol in rat streptozotocin-induced diabetes mellitus. Acta Med Okayama 36: $165-168$

44. Niohigaki I, Hagihava M, Tsunekawa H, Maseki M, Yagi K (1981) Lipid peroxide levels in serum lipoprotein fractions of diabetic patients. Biochem Med 25:273-278

Received: 27 January 1987

and in revised form: 4 August 1987

Dr. Maria F. Lopes-Virella

VA Medical Center - Research Service (151)

109 Bee Street

Charleston, SC 29403

USA 